\title{
Correction to: Conductive fabric patch with controllable porous structure and elastic properties for tissue engineering applications
}

Yuxiang Yin ${ }^{1}$, Jinhua $\mathrm{Mo}^{1}$, and Jianyong Feng ${ }^{1, *}$ (])

${ }^{1}$ College of Textile Science and Engineering, Zhejiang Sci-Tech University, Hangzhou 310018, China

Published online:

9 October 2020

(C) Springer Science+Business Media, LLC, part of Springer

Nature 2020

\section{Correction to:}

\section{J Mater Sci}

https://doi.org/10.1007/s10853-020-05219-9

In the original article the name of author Jianyong Feng was spelled incorrectly. It is correct here. The publisher apologizes for the error.
Publisher's Note Springer Nature remains neutral with regard to jurisdictional claims in published maps and institutional affiliations.

The original article can be found online at https:/ / doi.org/10.1007/s10853-020-05219-9.

Address correspondence to E-mail: jyfeng@zstu.edu.cn 